UDC 544.653.2/.3

PEROVSKITE-LIKE $\left(\mathrm{La}_{0.75} \mathrm{Ca}_{0.25}\right)_{0.95} \mathrm{Cr}_{1-\mathrm{x}} \mathrm{Fe}_{\mathrm{x}} \mathrm{O}_{3-\delta}$ AS POTENTIAL ELECTRODE MATERIALS FOR SYMMETRIC SOLID OXIDE FUEL CELLS

\author{
V.A. Kolotygin, A.I. Ivanov, N.B. Kostretsova, V.V. Kharton \\ Institute of Solid State Physics RAS \\ Chernogolovka, Moscow District, 2 Academician Ossipyan str., 142432 Russia \\ e-mail: kolotygin@issp.ac.ru
}

Received 28.05.2019

\begin{abstract}
The study is focused on the synthesis and characterization of $\left(\mathrm{La}_{0.75} \mathrm{Ca}_{0.25}\right)_{0.95} \mathrm{Cr}_{1-x} \mathrm{Fe}_{x} \mathrm{O}_{3-\delta}(x=$ 0.3 - 0.9)perovskites as potential materials for solid oxide fuel cell (SOFC) cathode and anode. These materials possessanorthorhombically-distorted structure at room temperature whilst heating above 800$1100 \mathrm{~K}$ induces reversible transformation into the rhombohedral symmetry. The transition temperature increases with iron content. The linear thermal expansion coefficients vary in the range $(10.5-11.1) \times 10^{-6}$ $K^{-1}$ and slightly grow on Fe-doping. The volume changes upon reduction are within $0.16 \%$. The electronic conductivity exhibits a thermally-activated character and increases on Fe introduction, in particular due to an enhancement of the number of sites available for electronic transfer; this trend is observed both under oxidizing and reducing conditions. The low level of the electronic conductivity seems to be responsible for an insufficient electrochemical activity of $\left(\mathrm{La}_{0.75} \mathrm{Ca}_{0.25}\right)_{0.95} \mathrm{Cr}_{1-x} \mathrm{Fe}_{x} \mathrm{O}_{3-\delta}$-based cathodes.Under anodic conditions, other factors, such as electrode microstructure or surface-related properties, affect the electrochemical behavior.
\end{abstract}

Keywords: perovskite, phase transition, thermal expansion, chemical expansion, total conductivity, polarization resistance.

DOI:10.32737/2221-8688-2019-3-373-385

\title{
Introduction
}

The reduction of operating temperature of Solid Oxide Fuel Cells (SOFC) and a partial replacement of hydrogen by other fuels, generally produced from hydrocarboncontaining sources,requires development of novel functional materials capable to operate adequately under necessary conditions. Conventional Ni-based composites used as SOFC anodes suffer from microstructural degradation with time or upon redox cycling and possible coking in hydrocarbon- or carbon monoxide-enriched atmospheres [1-3]. Chromite-based perovskites are considered to be possible alternative anode materials due to their high stability under reducing conditions and moderate volume and microstructural changes on reduction which decreases the risk of the electrode cracking or delamination from the solid electrolyte. However, significant limitation of $\mathrm{LaCrO}_{3-\delta}$ and related materialsis their insufficient conductivity, especially under reducing conditions, and low electrochemical activity towards oxidation processes which requires addition of surfaceactive agents into the anode layer [2, 4-6].

In recent 15-20 years it was demonstrated that appropriate doping in A- or B-sublattice may substantially improve the electrode properties of chromites both in oxidizing and reducing atmospheres. The latter factor is attractive for their simultaneous utilization as cathodes and anodes in symmetrical SOFCswhere both electrodes are prepared from the same material which simplifies the procedure of electrode coating and subsequent firing [5, 7-11]. The basic strategy of substitution in B-sublattice relates to introducing cations with variable oxidation state or oxygen coordination ( $\mathrm{Mn}, \mathrm{Fe}, \mathrm{Co}, \mathrm{Ni}$, $\mathrm{V})$ which makes possible generation of additional charge carriers and channels of their transfer, improvement of the oxygen ionic conductivity due to higher concentration of oxygen vacancies or modifying the surface- 
related properties. In particular, $(\mathrm{La}, \mathrm{Sr})(\mathrm{Cr}, \mathrm{Mn}) \mathrm{O}_{3-\delta}$ perovskites are considered to be among the most active $\mathrm{Ni}$-free anode materials due tocomparatively high performance $\mathrm{inH}_{2}$, hydrocarbons, alcohols and other fuels [5, 11-14]. Owing to the high stability and acceptable conductivity in both oxidizing and reducing atmospheres, this material has a great potential for utilization as both electrodes of symmetrical SOFCs $[8,12$, $15]$.

Fe-doped chromites represent another attractive group of perovskite-based anodes since these materials combine both acceptable stability in the anode atmosphere and the conductivity level necessary for ensuring good anode properties. In particular, in [7, 8] the performance of $(\mathrm{La}, \mathrm{Sr})(\mathrm{Cr}, \mathrm{Fe}) \mathrm{O}_{3-\delta}$ anodes was demonstrated to be superior as compared to that of Mn-substituted analogues measured under similar conditions, while the lowtemperature stabilization of the oxygen nonstoichiomentryenablesto preserve a comparatively high conductivity level (40-50 $\mathrm{S} / \mathrm{cm})$ even in reducing atmospheres. At the same time, $(\mathrm{La}, \mathrm{Sr})(\mathrm{Cr}, \mathrm{Fe}) \mathrm{O}_{3}$-based anodes

\section{Objective of the article}

The primarily objectiveof the work is to study the phase and structural stability, transport and thermomechanicalproperties of $\left(\mathrm{La}_{0.75} \mathrm{Ca}_{0.25}\right)_{0.95} \mathrm{Cr}_{1-\mathrm{x}} \mathrm{Fe}_{\mathrm{x}} \mathrm{O}_{3-\delta}$ perovskites and evaluate the electrochemical activity of showed moderate performance in hydrocarbon-, $\mathrm{CO}-, \mathrm{H}_{2} \mathrm{~S}-$ and even $\mathrm{PH}_{3-}$ containing fuels, with more stable operation in comparison with the conventional Ni-based anodes [10, 16-19]. However, Fe-doped chromites are reported to exhibit an enormous expansivity $(>1 \%$ in linear scale [7]) upon reduction which may be problematic for longterm utilization of the corresponding cell.

Previous studies on $(\mathrm{La}, \mathrm{Sr}, \mathrm{Ca}) \mathrm{FeO}_{3-}$ ${ }_{\delta}$ perovskites showed that a partial or complete substitution of $\mathrm{Ca}$ for $\mathrm{Sr}$ allows to modify the functional properties, particularly, to reduce the thermal and chemical expansion and improve, to some extent, the phase stability. Excessive amount of $\mathrm{Ca}$ is undesirable since it may lead to ordering of oxygen vacancies in the crystal lattice deteriorating the transport properties; this effect is substantially suppressed for Cr-containing ferrites [20-22]. Taking the above information into account, the present work is focused on evaluation of $\left(\mathrm{La}_{0.75} \mathrm{Ca}_{0.25}\right)_{0.95} \mathrm{Cr}_{1-\mathrm{x}} \mathrm{Fe}_{\mathrm{x}} \mathrm{O}_{3-\delta} \quad(0.3 \leq \mathrm{x} \leq 0.9)$ perovskites as potential cathode and anode materials of symmetrical SOFCs.

corresponding cathodes and anodes with a special emphasis on the relationships between the transport, electrochemical and structural behavior of these materials.

\section{Experimental}

Synthesis of $\quad\left(\mathrm{La}_{0.75} \mathrm{Ca}_{0.25}\right)_{0.95} \mathrm{Cr}_{1-}$ ${ }_{x} \mathrm{Fe}_{\mathrm{x}} \mathrm{O}_{3-\delta}(\mathrm{LCCF})$ solid solutions was carried out with glycine-nitrate processing (GNP) from $\mathrm{La}\left(\mathrm{NO}_{3}\right)_{3} \times 6 \mathrm{H}_{2} \mathrm{O}, \mathrm{Ca}\left(\mathrm{NO}_{3}\right)_{2}, \mathrm{Cr}\left(\mathrm{NO}_{3}\right)_{3} \times 9 \mathrm{H}_{2} \mathrm{O}$ and $\mathrm{FeC}_{2} \mathrm{O}_{4} \times 2 \mathrm{H}_{2} \mathrm{O}$ preliminary dissolved in 20 $\mathrm{mL}$ of concentrated nitric acid as precursors. The precise molar mass of the starting reactants which might be affected by possible water losses or other compositional changes with timewas determined with the thermogravimetric analysis (TGA) by hightemperature transformation of the corresponding precursor into $\mathrm{La}_{2} \mathrm{O}_{3}, \mathrm{CaO}$ or $\mathrm{Fe}$ in air or $\mathrm{H}_{2}$-Ar atmosphere until the constant mass was achieved. The water content was calculated from relative mass changes. The details of the GNP method may be found elsewhere ([7, 12] and references cited). The synthesized powder was consecutively ground in a mortar and annealed in a furnace at $1073-1573 \mathrm{~K}$. In order to obtain dense ceramics, the annealed powderswereuniaxially compacted in a press mould under 100-150 MPa pressure followed by sintering at $1673-1743 \mathrm{~K}$ in air.

$\mathrm{X}$-ray diffraction (XRD) analysis was carried out with a Siemens D-500BRAUNdiffractometerusing of $\mathrm{CuK}_{\alpha}$ irradiation in the $2 \theta$ range of $20-80^{\circ} \mathrm{C}$. The analysis of phase composition and calculation 
of lattice parameters was made with the use of Match andPowderCell 2.4software. Studies oftransport and thermo-mechanical properties were performed on rectangular-shaped bars obtained by cutting and subsequent polishing of ceramic pellets. The total conductivity was measured on direct current using a 4-probe technique in a laboratory-made tubular furnace in a flow of the required gas; the oxygen partial pressure $\left(\mathrm{p}\left(\mathrm{O}_{2}\right)\right)$ was controlled using an electrochemical oxygen sensor inserted into the tube. Thermomechanicalmeasurements were fulfilled in a vertical dilatometer Linseis V75 equipped with an electrochemical pump and sensor to ensure the necessary oxygen content in the gas atmosphere. The methodology of dilatometric measurements and calculation of the thermal/chemical expansion coefficients is discussed in $[12,22]$ and referenced therein.

Electrochemical properties were studied on symmetrical cells LCCF / LDC / LSGM / LDC / LCCF, where LSGM and LDC correspond to $\left(\mathrm{La}_{0.9} \mathrm{Sr}_{0.1}\right)_{0.98} \mathrm{Ga}_{0.8} \mathrm{Mg}_{0.2} \mathrm{O}_{3-\delta}$ and $\mathrm{Ce}_{0.6} \mathrm{La}_{0.4} \mathrm{O}_{2-\delta}$ used as the solid electrolyte and protective sublayer, respectively. For deposition of porous electrode layers on LSGM pellet (thickness $0.7-1.0 \mathrm{~mm}$, area $0.4-$ $0.5 \mathrm{~cm}^{2}$ ) a laboratory-made print-screening device was used. Each coating step was followed by firing the applied layers in air at $1473 \mathrm{~K}$. The polarization resistance measurements were carried out by a 2electrode method in a symmetrical configuration without applying current. $\mathrm{Pt}$ meshes were used as current collectors; no additional modifications of the electrodes such as preparation of composites, impregnation with catalytically active agents or coating with a metallic paste, were undertaken within the framework of the present study. The studies were carried out in a tubular furnace in $\mathrm{O}_{2}$-airAr or $\mathrm{H}_{2}-\mathrm{Ar}-\mathrm{H}_{2} \mathrm{O}$ mixtures using an oxygen sensor forp $\left(\mathrm{O}_{2}\right)$ control. The impedance spectra were collected using a potentio/galvanostate MetrohmAutolab (PGSTAT302N)in $1 \mathrm{MHz}-5 \mathrm{mHz}$ frequency range with $\mathrm{AC}$ amplitude of $50-100 \mathrm{mV}$. The microstructure of the electrode layers was studied using a LEO SUPRA 50VP (Carl Zeiss, Germany) scanning microscope.

\section{Results and discussion}

Fig. 1 shows XRD patterns of as-prepared $\left(\mathrm{La}_{0.75} \mathrm{Ca}_{0.25}\right)_{0.95} \mathrm{Cr}_{1-\mathrm{x}} \mathrm{Fe}_{\mathrm{x}} \mathrm{O}_{3-\delta}$.

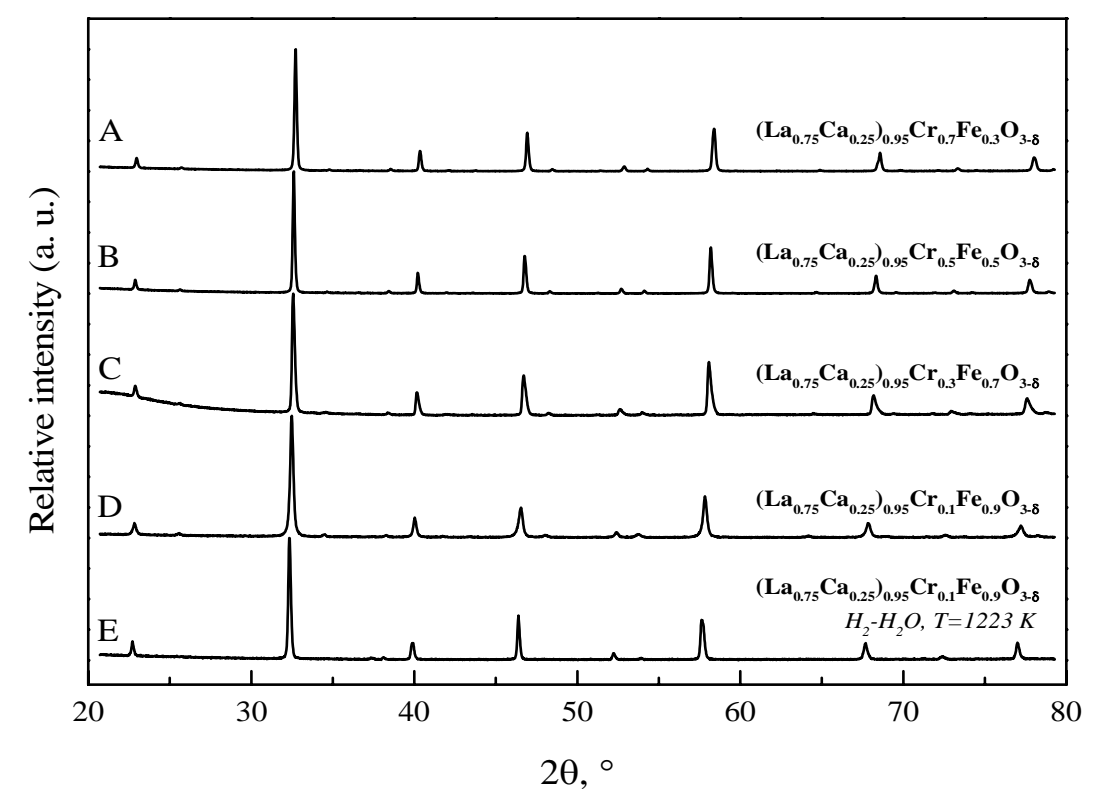

Fig. 1. XRD patterns of $\left(\mathrm{La}_{0.75} \mathrm{Ca}_{0.25}\right)_{0.95} \mathrm{Cr}_{1-\mathrm{x}} \mathrm{Fe}_{\mathrm{X}} \mathrm{O}_{3-\delta}$ perovskites, slowly cooled in air (A-D) and annealed in humidified $4 \% \mathrm{H}_{2}-\mathrm{Ar}(\mathrm{E})$. 
All the materials synthesized are nearly single-phase perovksites with the orthorhombic structure while reduction of $\mathrm{Fe}$ enriched compositions promotes the transition into the cubic symmetry.Doping with $\mathrm{Fe}$ increases the cell parameters (Table 1) in accordance with larger radii of $\mathrm{Fe}^{3+}$ and $\mathrm{Fe}^{4+}$ cations in comparison with the chromium analogues [23]. Moreover, substitution of iron for chromium might enhance the oxygen deficiency leading to an increase of ratio of 3fold charged cations to 4-fold ones; this fact requires verification by measuring the oxygen content under ambient conditions or studying the cation state by X-ray photoelectron spectroscopy, Mössbauer spectroscopy or other appropriate techniques. The same factors might be responsible for slight increment of the thermal expansion coefficients with iron content (Fig. 2, Table 1).

Table 1. Unit cell parameters, thermal expansion coefficients and chemical expansion on reductionof air-prepared $\left(\mathrm{La}_{0.75} \mathrm{Ca}_{0.25}\right)_{0.95} \mathrm{Cr}_{1-\mathrm{x}} \mathrm{Fe}_{\mathrm{x}} \mathrm{O}_{3-\delta}$ ceramics in $\mathrm{CO}-\mathrm{CO}_{2}$ atmospheres $\left(\mathrm{p}\left(\mathrm{O}_{2}\right)=\right.$ $\left.10^{-12}-10^{-20} \mathrm{~atm}\right)$

\begin{tabular}{|c|c|c|c|c|c|c|}
\hline Composition & $\mathrm{a}, \AA$ & $\mathrm{b}, \AA$ & $\mathrm{c}, \AA$ & $\mathrm{V}, \AA^{3}$ & $\begin{array}{c}\mathrm{TEC} \times 10^{6}, \\
\mathrm{~K}^{-1}\end{array}$ & $\begin{array}{c}\frac{L_{\text {air }}-L_{\mathrm{CO} / \mathrm{CO} 2}}{L_{\text {air }}}, \% \\
(T, K)\end{array}$ \\
\hline$\left(\mathrm{La}_{0.75} \mathrm{Ca}_{0.25}\right)_{0.95} \mathrm{Cr}_{0.7} \mathrm{Fe}_{0.3} \mathrm{O}_{3-\delta}$ & $5.477(2)$ & $7.745(2)$ & $5.465(2)$ & $231.8(2)$ & $10.5 \pm 0.1$ & $0.13(1223)$ \\
\hline as-prepared in air & & & & & & $0.16(973)$ \\
\hline$\left(\mathrm{La}_{0.75} \mathrm{Ca}_{0.25}\right)_{0.95} \mathrm{Cr}_{0.5} \mathrm{Fe}_{0.5} \mathrm{O}_{3-\delta}$ & $5.490(2)$ & $7.765(2)$ & $5.479(2)$ & $233.5(2)$ & $10.8 \pm 0.1$ & $0.13(1223)$ \\
\hline as-prepared in air & & & & & & $0.14(973)$ \\
\hline$\left(\mathrm{La}_{0.75} \mathrm{Ca}_{0.25}\right)_{0.95} \mathrm{Cr}_{0.3} \mathrm{Fe}_{0.7} \mathrm{O}_{3-\delta}$ & $5.504(2)$ & $7.787(2)$ & $5.487(2)$ & $235.2(2)$ & $10.7 \pm 0.1$ & $0.11(1223)$ \\
\hline as-prepared in air & & & & & & $0.10(973)$ \\
\hline$\left(\mathrm{La}_{0.75} \mathrm{Ca}_{0.25}\right)_{0.95} \mathrm{Cr}_{0.1} \mathrm{Fe}_{0.9} \mathrm{O}_{3-\delta}$ & $5.527(2)$ & $7.833(2)$ & $5.524(2)$ & $239.2(2)$ & $11.1 \pm 0.1$ & \\
\hline as-prepared in air & & & & & & \\
\hline$\left(\mathrm{La}_{0.75} \mathrm{Ca}_{0.25}\right)_{0.95} \mathrm{Cr}_{0.1} \mathrm{Fe}_{0.9} \mathrm{O}_{3-\delta}$ & $2014(9)$ & & & $1 / 4 \times 239.8$ & & \\
\hline reduced in wet $\mathrm{H}_{2}-\mathrm{Ar}, 1273 \mathrm{~K}$ & $3.7+(2)$ & & & (4) & & \\
\hline
\end{tabular}

Cell parameters correspond to the orthorhombic (Pnma) or cubic (Pm3m) structure for samples prepared in air or annealed in wet $\mathrm{H}_{2}$-Ar, respectively. $\mathrm{p}\left(\mathrm{O}_{2}\right)$ in $\mathrm{CO}-\mathrm{CO}_{2}$ mixture was $\sim 10^{-13}$ atm $(1223 \mathrm{~K})$ and $\sim 10^{-19} \mathrm{~atm}(973 \mathrm{~K})$. TEC values correspond to the 300-1273 $\mathrm{K}$ temperature range in air.

It should be noticed that the effect of iron content on the chemical expansion is different from common trends known for ferrites where replacement of iron with foreign cations generally reduces oxygen losses and resultant volume changes $[7,24,25]$. The abnormal behavior detected in the study might be associated with the structural transformation discussed below which occur in the considered temperature range, or with a comparatively high oxygen non-stoichiometry for Fe-enriched compositions in air at elevated temperatures, and subsequent reduction might lead to somewhat lower changes of oxygen content as compared to that of nearly stoichiometric compositions with lower iron content. One should also take into account that the difference in the expansivity is rather insignificant and comparable to the measurement uncertainty. Irrespective of origins of the unusual behavior, the volume changes on reduction in $\mathrm{CO}-\mathrm{CO}_{2}$ atmosphere are $0.10-0.16 \%$ in the linear scale which is substantially lower as compared to the values reported for $\left(\mathrm{La}_{0.75} \mathrm{Sr}_{0.25}\right)_{0.95} \mathrm{Cr}_{1-\mathrm{x}} \mathrm{Fe}_{\mathrm{x}} \mathrm{O}_{3-\delta}[7]$ and much closer to the typical level of isothermal expansion of chromite-based materials upon reduction [12, 24-26]. 


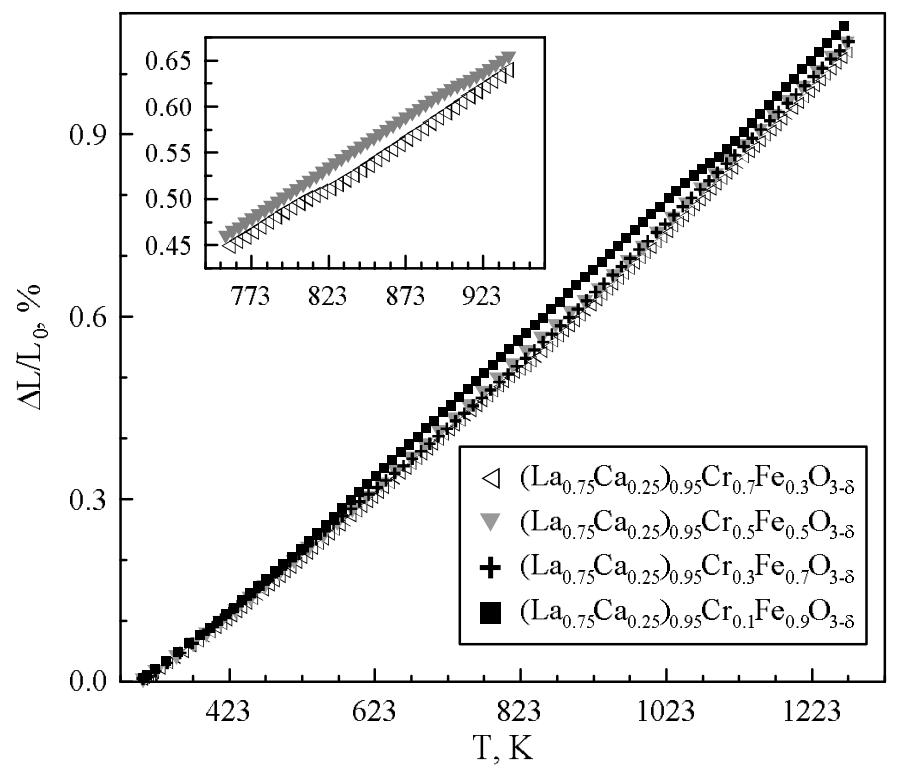

Fig. 2. Relative length changes of $\left(\mathrm{La}_{0.75} \mathrm{Ca}_{0.25}\right)_{0.95} \mathrm{Cr}_{1-\mathrm{x}} \mathrm{Fe}_{\mathrm{x}} \mathrm{O}_{3-\delta}$ ceramics on cooling in air. The inset shows zoomed view of the dilatometric curves in the 743-953 K temperature range.

A peculiarity of the studied materials is the presence of a kink on the dilatometric curves (inset in Fig. 2) which is reproducible upon heating and cooling observableboth in air and argon atmospheres. In accordance with literature data [4, 26-30], this behavior might be associated with reversible $1^{\text {st }}$ order transition of the orthorhombic structure into the rhombohedral one. For the title materials, this effect occurs at significantly higher temperatures as compared to some other chromitesshown in Table 2 which might originate from an increase of transition temperatures upon Ca- or Fe-doping; the effect of $\mathrm{Fe}$ introduction on the transition temperature confirms this suggestion. Verification of the structural changes requires high-temperature XRD analysis; nevertheless, from the viewpoint of potential application of the materials as SOFC electrodes, the negligible volume changes induced by this effect as well as moderate chemical expansivity and the values of TECs comparable to those of typical electrolytes [31] suggest an adequate mechanical compatibility between the electrochemical cell components.

Table 2. Comparison of the phase transition temperatures for selected $\mathrm{LaCrO}_{3}$-based perovskites

\begin{tabular}{|c|c|c|}
\hline Composition & $\mathrm{T}_{\text {ph.trans }}, \mathrm{K}$ & Reference \\
\hline $\mathrm{LaCrO}_{3-\delta}$ & 520 & {$[27,28]$} \\
& 560 & {$[29]$} \\
$\mathrm{La}_{0.9} \mathrm{Ca}_{0.1} \mathrm{CrO}_{3-\delta}$ & 580 & {$[27]$} \\
$\mathrm{La}_{0.9} \mathrm{Sr}_{0.1} \mathrm{CrO}_{3-\delta}$ & 340 & {$[27]$} \\
$\mathrm{LaCr}_{0.9} \mathrm{Mg}_{0.1} \mathrm{O}_{3-\delta}$ & 600 & {$[27]$} \\
$\mathrm{LaCr}_{0.8} \mathrm{Mg}_{0.2} \mathrm{O}_{3-\delta}$ & 620 & {$[27]$} \\
$\left(\mathrm{La}_{0.9} \mathrm{Sr}_{0.1}\right)_{0.98} \mathrm{Cr}_{0.9} \mathrm{Mg}_{0.1} \mathrm{O}_{3-\delta}$ & $336 \pm 10$ & {$[26]$} \\
$\left(\mathrm{La}_{0.75} \mathrm{Ca}_{0.25}\right)_{0.95} \mathrm{Cr}_{0.7} \mathrm{Fe}_{0.3} \mathrm{O}_{3-\delta}$ & $815 \pm 5$ & This work \\
$\left(\mathrm{La}_{0.75} \mathrm{Ca}_{0.25}\right)_{0.95} \mathrm{Cr}_{0.5} \mathrm{Fe}_{0.5} \mathrm{O}_{3-\delta}$ & $910 \pm 5$ & This work \\
$\left(\mathrm{La}_{0.75} \mathrm{Ca}_{0.25}\right)_{0.95} \mathrm{Cr}_{0.1} \mathrm{Fe}_{0.9} \mathrm{O}_{3-\delta}$ & $1080 \pm 5$ & This work \\
$\left(\mathrm{La}_{0.9} \mathrm{Sr}_{0.1}\right)_{0.98} \mathrm{Cr}_{0.8} \mathrm{Mg}_{0.1} \mathrm{Fe}_{0.1} \mathrm{O}_{3-\delta}$ & $405 \pm 10$ & {$[26]$} \\
$\left(\mathrm{La}_{0.9} \mathrm{Sr}_{0.1}\right)_{0.98} \mathrm{Cr}_{0.6} \mathrm{Mg}_{0.1} \mathrm{Fe}_{0.3} \mathrm{O}_{3-\delta}$ & $545 \pm 5$ & {$[26]$} \\
$\mathrm{LaCr}_{0.9} \mathrm{Ni}_{0.1} \mathrm{O}_{3-\delta}$ & 640 & {$[28]$} \\
$\mathrm{LaCr}_{0.8} \mathrm{Ni}_{0.2} \mathrm{O}_{3-\delta}$ & 670 & {$[28]$} \\
$\left(\mathrm{La}_{0.9} \mathrm{Sr}_{0.1}\right)_{0.95} \mathrm{Cr}_{0.85} \mathrm{Mg}_{0.1} \mathrm{Ni}_{0.05} \mathrm{O}_{3-\delta}$ & $360 \pm 10$ & {$[30]$} \\
\hline \multicolumn{2}{|c}{}
\end{tabular}


Increasing iron content leads to an enhancement of the total conductivity; this trend is observed both in air and in wet $\mathrm{H}_{2}-\mathrm{Ar}$ (Fig. 3)and is opposite to the results obtained for $\left(\mathrm{La}_{0.75} \mathrm{Sr}_{0.25}\right)_{0.95} \mathrm{Cr}_{1-\mathrm{x}} \mathrm{Fe}_{\mathrm{x}} \mathrm{O}_{3-\delta}[7]$. Whereas in the latter case the negative effect of iron content on the conductivity was attributed toits essentially constant oxidation state irrespective to $\mathrm{Cr}$ :Fe ratiowhich suggests exclusion of $\mathrm{Fe}$ species from participation in the electron transfer, in the studied materials the conductivity seems to be governed by other factors.

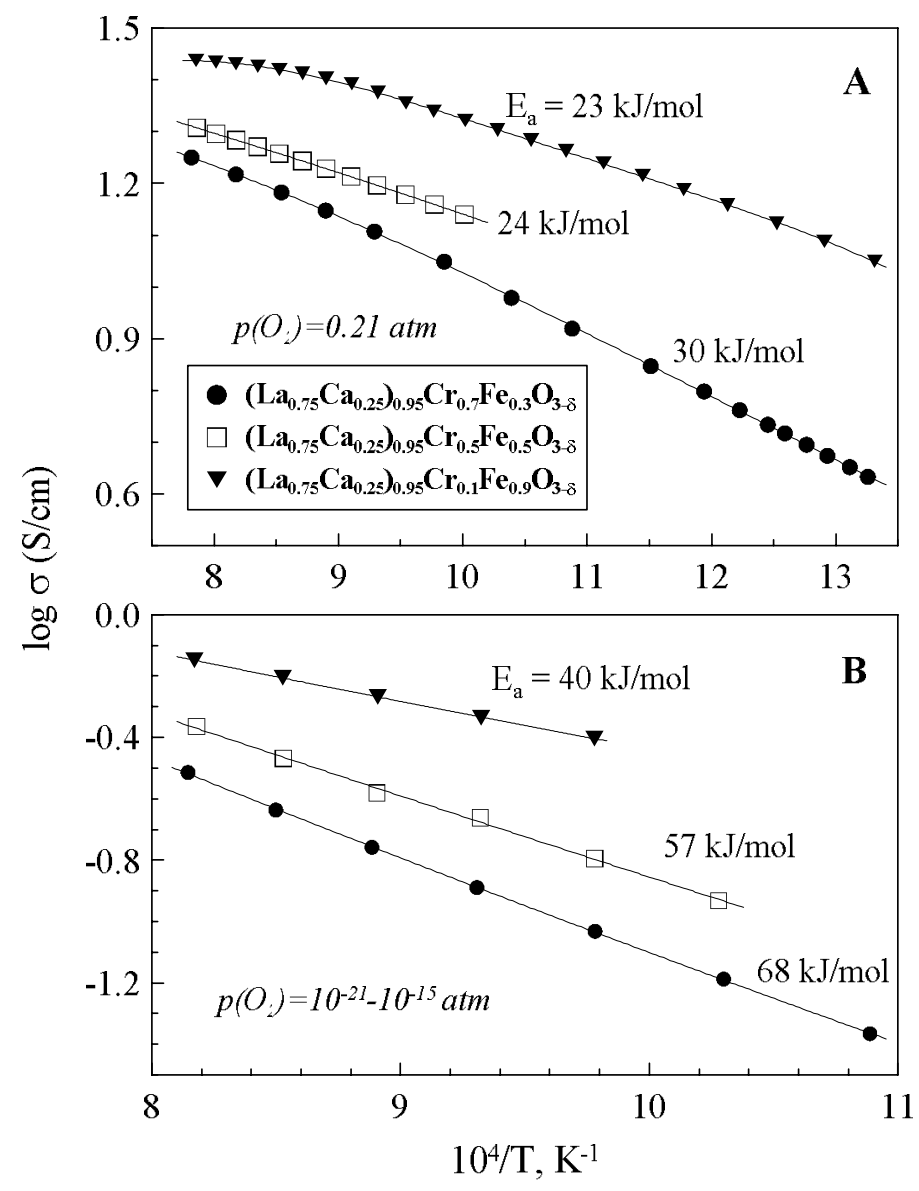

Fig. 3. Temperature dependencies of the total conductivity of $\left(\mathrm{La}_{0.75} \mathrm{Ca}_{0.25}\right)_{0.95} \mathrm{Cr}_{1-\mathrm{x}} \mathrm{Fe}_{\mathrm{x}} \mathrm{O}_{3-\delta}$ ceramics in air (A) and in wet $4 \% \mathrm{H}_{2}$-Ar mixture (B). The activation energies of the total conductivity are marked near the corresponding data.

It should be noted that similar contradictions are quite typical for chromitebased materials [5, 32-35] and may be associated with specific factors such as large differences in energy levels between $\mathrm{Cr}^{3+}$ and guest cations significantly affecting the probability of residence of charge carriers on these atoms or percolation between the species with close energies which is affected by oxygen nonstoichiometry, lattice symmetry, cell parameters, etc. The conductivity of $\left(\mathrm{La}_{0.75} \mathrm{Sr}_{0.25}\right)_{0.95} \mathrm{Cr}_{1-\mathrm{x}} \mathrm{Fe}_{\mathrm{x}} \mathrm{O}_{3-\delta}$ exhibits a thermally-activated character; the activation energies decrease with iron content (Fig. 3) suggesting that the electronic transport of presumably p-type electronic charge carriers proceeds more rapidly via $\mathrm{Fe}-\mathrm{O}-\mathrm{Fe}$ channels. For $\mathrm{x}=0.9$, a slight tendency towards theconductivity maximum typical for ferritebased materials [21, 24] is observed in air at high temperatures (Fig. 3a) associated with the increase of oxygen nonstoichiometry leading to lower concentration of charge carriers and break of conductive channels. The conductivity varies in the range of 10-30 and 0.1-1 S/cm under cathode and anode 
conditions, respectively. Obviously, this level is insufficient for an adequate operation ofthe corresponding electrodes, especially in reducing atmospheres which requires an improvement of current collection, for example, by fabrication of composites with metallic phases.

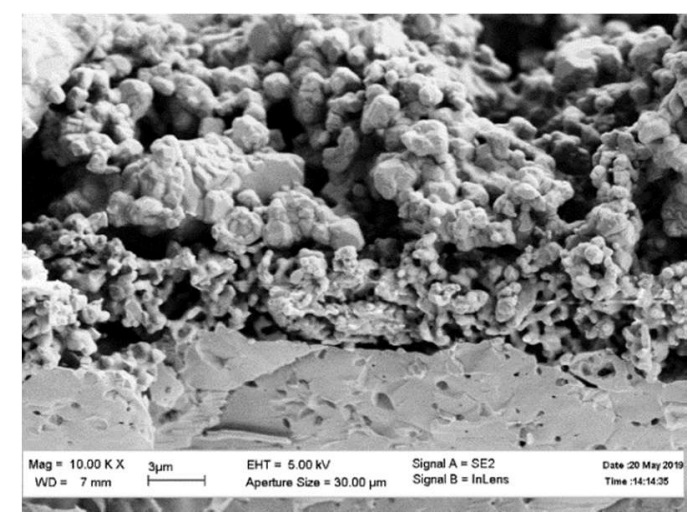

A
Electrode

layers

$\left(\mathrm{La}_{0.75} \mathrm{Ca}_{0.25}\right)_{0.95} \mathrm{Cr}_{0.7} \mathrm{Fe}_{0.3} \mathrm{O}_{3-\delta}$ presented in Fig. 4 show a nonuniform porosity and particle size distribution, although one should not exclude a possibility of microstructural changes during the electrode testing. No cracks in the electrode layer or its delamination from the electrolyte were detected.

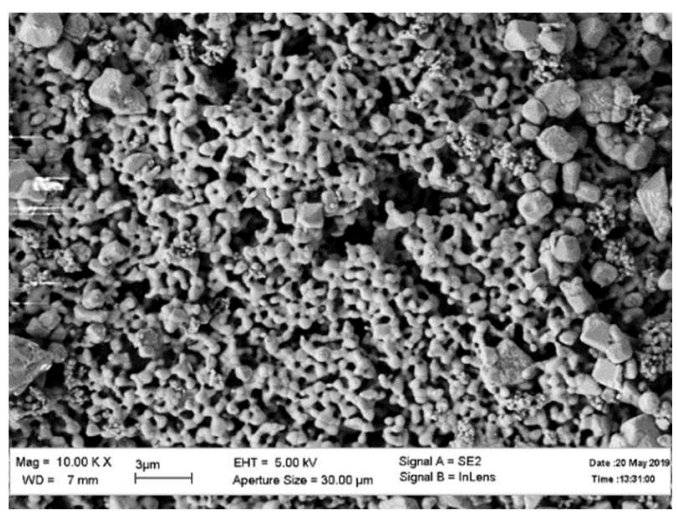

B

Fig. 4. Cross-section (A) and top view (B) of a cell with $\left(\mathrm{La}_{0.75} \mathrm{Ca}_{0.25}\right)_{0.95} \mathrm{Cr}_{0.7} \mathrm{Fe}_{0.3} \mathrm{O}_{3-\delta}$ electrode layer after testing under anode conditions.

Fig. 5illustrates examples of the impedance spectra for $\left(\mathrm{La}_{0.75} \mathrm{Ca}_{0.25}\right)_{0.95} \mathrm{Cr}_{0.7} \mathrm{Fe}_{0.3} \mathrm{O}_{3-\delta} \quad$ and $\left(\mathrm{La}_{0.75} \mathrm{Ca}_{0.25}\right)_{0.95} \mathrm{Cr}_{0.3} \mathrm{Fe}_{0.7} \mathrm{O}_{3-\delta}$ collected under cathodic and anodic conditions. For both electrodes, the Ohmic resistance decreases as the oxygen partial pressure rises in accordance with the electronic conductivity of the electrode materials. The polarization losses show a correlation with the content of the electrochemically-active component in the gas mixture, i.e. $\mathrm{O}_{2}$ or $\mathrm{H}_{2}$ for cathode and anode conditions, respectively. While these effects are similar for both electrode compositions, the impact of $\mathrm{Cr}$ :Fe ratio differs for various testing conditions. $\left(\mathrm{La}_{0.75} \mathrm{Ca}_{0.25}\right)_{0.95} \mathrm{Cr}_{0.3} \mathrm{Fe}_{0.7} \mathrm{O}_{3-\delta}$ cathode exhibits lower Ohmic and polarization resistance as compared to the material with higher $\mathrm{Cr}$ content; this trend is not surprising taking into account better conductivity of Fe-rich compositions (Fig. 3) and well-known improved catalytic activity of ferrite-based compositions in redox processes [36-38].The low-frequency arc for the Fe-enriched cathode is more suppressed (Fig. 5D) than that for $\left(\mathrm{La}_{0.75} \mathrm{Ca}_{0.25}\right)_{0.95} \mathrm{Cr}_{0.7} \mathrm{Fe}_{0.3} \mathrm{O}_{3-\delta}$ which may be associated withmicro-structural factors or a mechanism of oxygen adsorption or surface diffusion promoted by the higher electronic and ionic conductivity. However, in reductive atmospheresthe introduction of iron into the electrode composition has a negative effect even despitehigher conductivity in comparison with $\quad\left(\mathrm{La}_{0.75} \mathrm{Ca}_{0.25}\right)_{0.95} \mathrm{Cr}_{0.7} \mathrm{Fe}_{0.3} \mathrm{O}_{3-\delta}$ and negligible difference of the thermal and chemical expansion. It should be remembered that the phase composition of $\left(\mathrm{La}_{0.75} \mathrm{Ca}_{0.25}\right)_{0.95} \mathrm{Cr}_{0.3} \mathrm{Fe}_{0.7} \mathrm{O}_{3-\delta} \quad$ annealed insimilar $\mathrm{H}_{2} \mathrm{O}-\mathrm{H}_{2}-\mathrm{Ar}$ atmosphere exhibited no additional phases. 


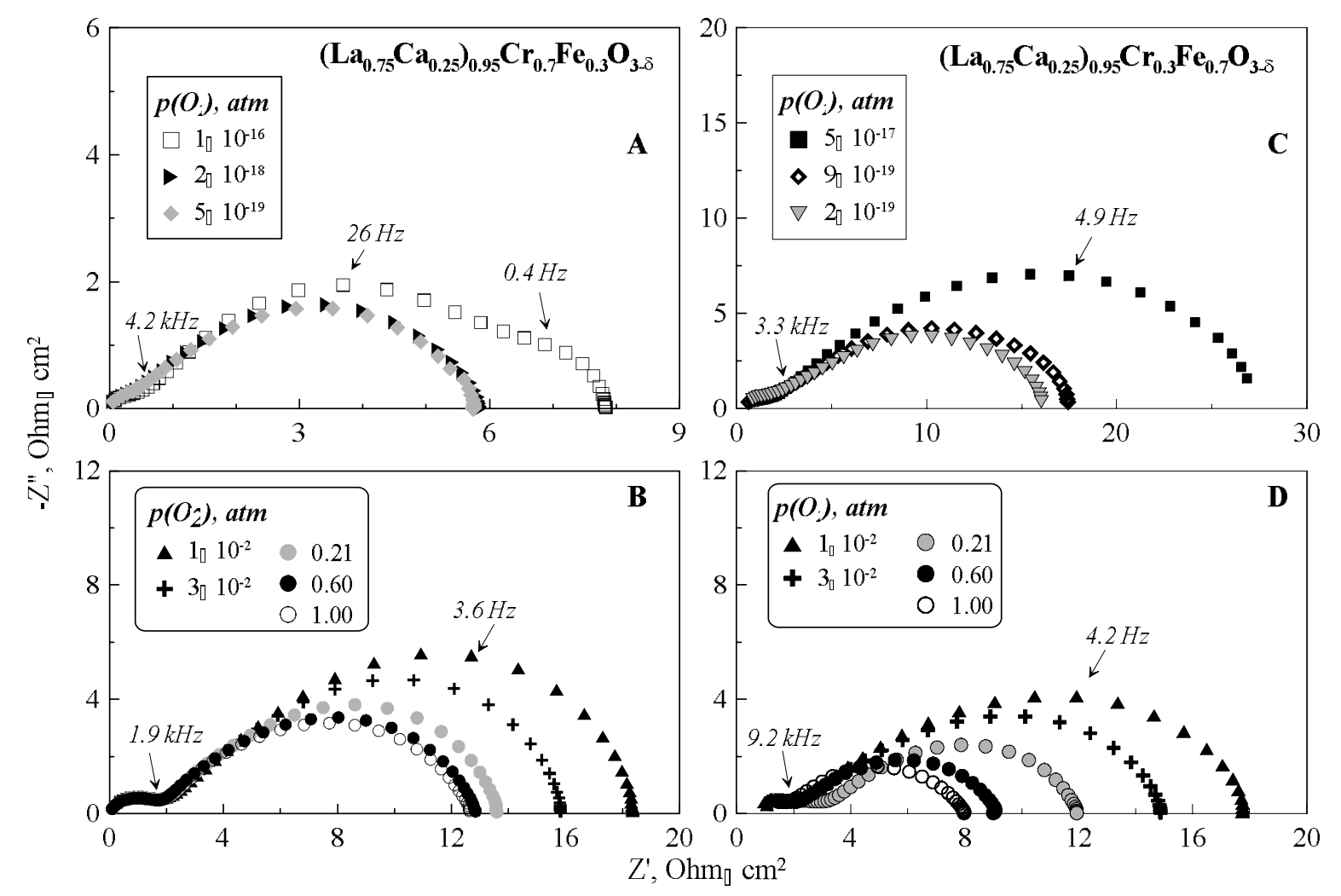

Fig. 5. Impedance spectra corrected for the electrode area and Ohmic resistance for $\left(\mathrm{La}_{0.75} \mathrm{Ca}_{0.25}\right)_{0.95} \mathrm{Cr}_{0.7} \mathrm{Fe}_{0.3} \mathrm{O}_{3-\delta}(\mathrm{A}, \mathrm{B})$ and $\left(\mathrm{La}_{0.75} \mathrm{Ca}_{0.25}\right)_{0.95} \mathrm{Cr}_{0.3} \mathrm{Fe}_{0.7} \mathrm{O}_{3-\delta}(\mathrm{C}, \mathrm{D})$ under reducing (A, $\mathrm{C})$ and oxidizing $(\mathrm{B}, \mathrm{D})$ conditions.

According to Fig. 6, the activation energies of the electrode reactions both in reducing and oxidizing atmospheres are substantially higher for $\left(\mathrm{La}_{0.75} \mathrm{Ca}_{0.25}\right)_{0.95} \mathrm{Cr}_{0.3} \mathrm{Fe}_{0.7} \mathrm{O}_{3-\delta}$ as compared to the $\mathrm{Cr}$-rich analogue regardless of the opposite trends in the conductivity behavior. This fact suggests that at least for one electrode composition the electrochemical activity is governed by factors independent of electron supply/removal to/from electrochemicallyactive sites. This suggestion is confirmed bysubstantially lower values of $\mathrm{E}_{\mathrm{a}}$ for the total conductivity (Fig. 3) than those for the electrochemical activity. The observed trends are not typical for most perovskite-based electrode [2, 7, 8] where the electronic conductivity is considered to be the major performance-determined factor, and might be attributed to differences in the microstructure or excessive formation of oxygen vacancies on the surface of Fe-enriched perovskiesleading to local ordering thathas the influence on the electro-catalytic properties. At the same time,

the structural transition for $\left(\mathrm{La}_{0.75} \mathrm{Ca}_{0.25}\right)_{0.95} \mathrm{Cr}_{0.7} \mathrm{Fe}_{0.3} \mathrm{O}_{3-\delta}$ occurs at $\sim 815$ $\mathrm{K}$, i.e. all the electrochemical tests were carried out on the material with rhombohedral or cubic structure. As for $\left(\mathrm{La}_{0.75} \mathrm{Ca}_{0.25}\right)_{0.95} \mathrm{Cr}_{0.3} \mathrm{Fe}_{0.7} \mathrm{O}_{3-\delta}$, the structural transformation occurred in the temperature rangewhere the electrochemical studies were carried out thatcould substantially affect its electrochemical behavior.

While decreasing hydrogen pressure over $\left(\mathrm{La}_{0.75} \mathrm{Ca}_{0.25}\right)_{0.95} \mathrm{Cr}_{0.7} \mathrm{Fe}_{0.3} \mathrm{O}_{3-\delta}$ anode leads to an appearance of additional low-frequency semicircle (Fig.5A) associated with retarded gas-phase diffusion, the $\left(\mathrm{La}_{0.75} \mathrm{Ca}_{0.25}\right)_{0.95} \mathrm{Cr}_{0.3} \mathrm{Fe}_{0.7} \mathrm{O}_{3-\delta} \quad$ anode demonstrates a substantial enlargement of the intermediate-frequency arc (Fig. 4C) suggesting a higher role of surface-associated processes. Obviously, this phenomenon deserves further studies. One should remind that the increase of iron content in $\left(\mathrm{La}_{0.75} \mathrm{Sr}_{0.25}\right)_{0.95} \mathrm{Cr}_{1-\mathrm{x}} \mathrm{Fe}_{\mathrm{x}} \mathrm{O}_{3-\delta}$ also resulted in a deterioration of the electrochemical activity, 
presumably due to lower electronic for instance, by fabrication of composite conductivity [7]. Irrespective of the origin of anodes, introduction of catalytically-active such unexpected electrode behavior, the high components or by a proper application of the level of the polarization resistance makes it current-collecting layer. necessary to modify the electrode composition,

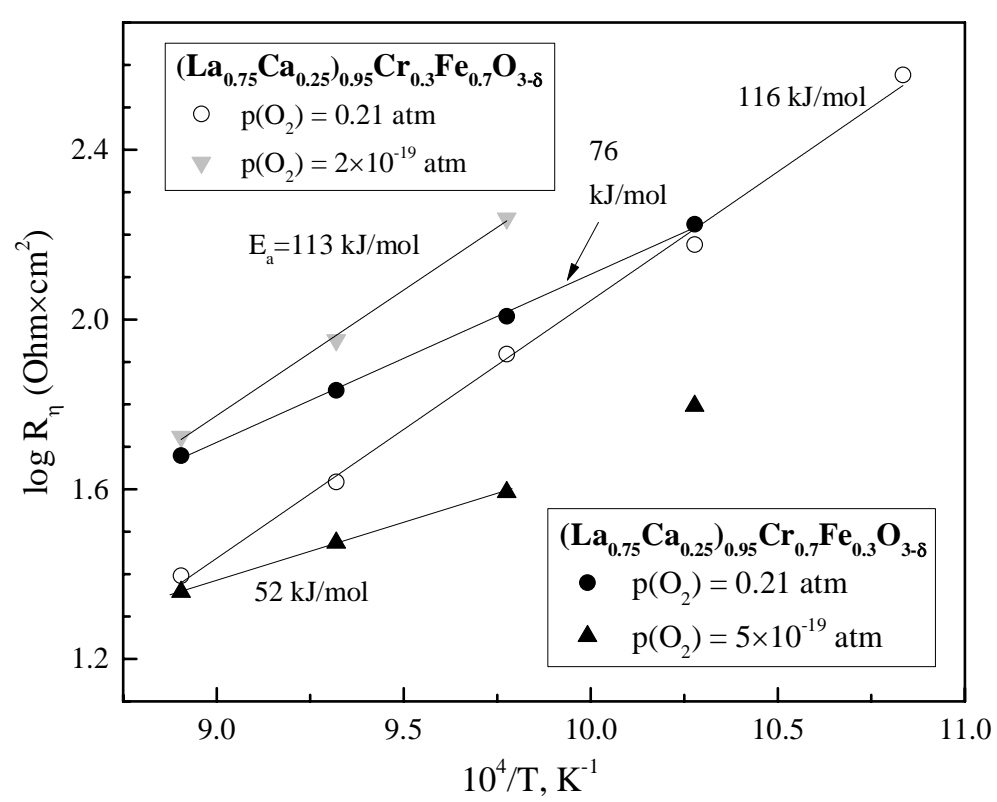

Fig. 6. Temperature dependencies of the polarization resistance of $\left(\mathrm{La}_{0.75} \mathrm{Ca}_{0.25}\right)_{0.95} \mathrm{Cr}_{1-\mathrm{x}} \mathrm{Fe}_{\mathrm{x}} \mathrm{O}_{3-\delta}$ electrodes in $\mathrm{O}_{2}$ and wet $4 \% \mathrm{H}_{2}$-Ar atmospheres. The activation energies of the reciprocal total polarization resistance are marked near the corresponding data.

\section{Conclusions}

Increasing iron content in under anode conditions is, however, different $\left(\mathrm{La}_{0.75} \mathrm{Sr}_{0.25}\right)_{0.95} \mathrm{Cr}_{1-\mathrm{x}} \mathrm{Fe}_{\mathrm{x}} \mathrm{O}_{3-\mathrm{\delta}}$ perovskites leads to to that of the conductivity at low $\mathrm{p}\left(\mathrm{O}_{2}\right)$ higher electronic conductivity, thermal indicating that other factors such as the expansion coefficient and electrochemical structural transformation, anode microstructure activity of the corresponding cathodes. or ordering of the surface oxygen Moreover, the temperature of the structural vacancies,are responsible for the anode transition "orthorhombic" - "rhombohedral" behavior. The high values of the polarization shiftswith Fe-dopingtowards higher resistance require optimization of the electrode temperatures. The influence of $\mathrm{Cr}$ :Fe ratio layers.

\section{Acknowledgements}

This work was supported by the Russian Science Foundation (grant 17-79-30071). The facilities and experimental technique for dilatometric testsin controlled atmospheres were developed with support by the State Task of the Institute of Solid State Physics RAS.

\section{References}

1. Jiang S.P., Chan S.H. A review of anode cells. J. Mater. Sci. 2004, vol. 39, iss. 14, materials development in solid oxide fuel pp. 4405-4439. 
2. Tsipis E.V., Kharton V.V. Electrode materials and reaction mechanisms in solid oxide fuel cells: a brief review. III. Recent trends and selected methodological aspects. J. Solid State Electrochem. 2011, vol. 15, iss. 5, pp. 1007-1040.

3. McIntosh S., Gorte R.J. Recent developments on anodes for direct fuel utilization in SOFC.Chem. Rev. 2004, vol. 104 , iss. 10 , pp. $4845-4866$.

4. Fergus J.W. Lanthanum chromite-based materials for solid oxide fuel cell interconnects. Solid State Ionics.2004, vol. 171, iss. 1-2, pp. 1-15.

5. Tao S., Irvine J.T.S. Synthesis and Characterization of $\left(\mathrm{La}_{0.75} \mathrm{Sr}_{0.25}\right)$ $\mathrm{Cr}_{0.5} \mathrm{Mn}_{0.5} \mathrm{O}_{3-\delta}$, a Redox-Stable, Efficient Perovskite Anode for SOFCs. $J$. Electrochem. Soc. 2004, vol. 151, iss.2, pp. A252-A259.

6. Yasuda I., Hikita T. Electrical Conductivity and Defect Structure of CalciumDopedLanthanum Chromites. J. Electrochem. Soc. 1993, vol. 140, iss. 6, pp. 1699-1704.

7. Lü M.F., Tsipis E.V., Waerenborgh J.C., Yaremchenko A.A., Kolotygin V.A., Bredikhin S., Kharton V.V. Thermomechanical, transport and anodic properties of perovskite-type $\left(\mathrm{La}_{0.75} \mathrm{Sr}_{0.25}\right)_{0.95} \mathrm{Cr}_{1-\mathrm{x}} \mathrm{Fe}_{\mathrm{x}} \mathrm{O}_{3-\delta} . \quad J . \quad$ Power Sources. 2012, vol. 206, pp. 59-69.

8. Kolotygin V.A., Tsipis E.V., Lü M.F., Pivak Y.V., Yarmolenko S.N., Bredikhin S.I., Kharton V.V.Functional properties of SOFC anode materials based on $\mathrm{LaCrO}_{3}$, $\mathrm{La}(\mathrm{Ti}, \mathrm{Mn}) \mathrm{O}_{3}$ and $\mathrm{Sr}(\mathrm{Nb}, \mathrm{Mn}) \mathrm{O}_{3}$ perovskites: A comparative analysis. Solid State Ionics. 2013, vol. 251, pp. 28-33.

9. Kobsiriphat W., Madsen B.D., Wang Y., Marks L.D., Barnett S.A. $\mathrm{La}_{0.8} \mathrm{Sr}_{0.2} \mathrm{Cr}_{1-}$ ${ }_{x} \mathrm{Ru}_{\mathrm{x}} \mathrm{O}_{3-\delta}-\mathrm{Gd}_{0 .} 1 \mathrm{Ce}_{0.9} \mathrm{O}_{1.95}$ solid oxide fuel cell anodes: $\mathrm{Ru}$ precipitation and electrochemical performance. Solid State Ionics. 2009, vol. 180, iss. 2-3, pp. 257-264.

10.Danilovic N., Vincent A., Luo J.L., Chuang K.T., Hui R., Sanger A.R. Correlation of Fuel Cell Anode Electrocatalytic and ex situ Catalytic Activity of Perovskites $\mathrm{La}_{0.75} \mathrm{Sr}_{0.25} \mathrm{Cr}_{0.5} \mathrm{X}_{0.5} \mathrm{O}_{3-\delta}(\mathrm{X}=\mathrm{Ti}, \mathrm{Mn}, \mathrm{Fe}, \mathrm{Co}$,
Chem. Mater.2009, vol. 22, iss. 3, pp. 957965.

11. Peña-Martínez J., Marrero-López D., Pérez-Coll D., Ruiz-Morales J.C., Núñez P. Performance of XSCoF (X = Ba, La and $\mathrm{Sm})$ and $\mathrm{LSCrX}^{\prime}\left(\mathrm{X}^{\prime}=\mathrm{Mn}, \mathrm{Fe}\right.$ and $\left.\mathrm{Al}\right)$ perovskite-structure materials on LSGM electrolyte for IT-SOFC. Electrochim. Acta.2007, vol. 178, iss. 9, pp. 101-113.

12. Kharton V.V., Tsipis E.V., Marozau I.P. Viskup A.P., Frade J.R., Irvine J.T.S. Mixed conductivity and electrochemical behavior of $\left(\mathrm{La}_{0.75} \mathrm{Sr}_{0.25}\right)_{0.95} \mathrm{Cr}_{0.5} \mathrm{Mn}_{0.5} \mathrm{O}_{3-\delta}$. Solid State Ionics.2007, vol. 178, iss. 1-2, pp. 101-113.

13. Jiang S.P., Ye Y., He T., Ho S.B. Nanostructured palladium$\mathrm{La}_{0.75} \mathrm{Sr}_{0.25} \mathrm{Cr}_{0.5} \mathrm{Mn}_{0.5} \mathrm{O}_{3} / \mathrm{Y}_{2} \mathrm{O}_{3}-\mathrm{ZrO}_{2}$ composite anodes for direct methane and ethanol solid oxide fuel cells. J. Power Sources.2008, vol. 185, iss. 1, pp. 179-182.

14. Tan W., Zhong Q., Xu D., Yan H., Zhu X. Catalytic activity and sulfur tolerance for Mn-substituted $\mathrm{La}_{0.75} \mathrm{Sr}_{0.25} \mathrm{CrO}_{3 \pm \delta}$ in gas containing $\mathrm{H}_{2}$ S. Int. J. Hydr. Energy.2013, vol. 38, iss. 36, pp. 16656-16664.

15. Ruiz-Morales J.C., Canales-Vázquez J., Ballesteros-Pérez B., Peña-Martínez J., Marrero-López D., Irvine J.T.S., Núñez P. LSCM-(YSZ-CGO) composites as improved symmetrical electrodes for solid oxide fuel cells. J. Eur. Ceram. Soc. 2007, vol. 27, iss. 13-15, pp. 4223-4227.

16. Yuan C., Zhou Y., Qian J., Ye. X, Zhan Z., Wang $\mathrm{S}$., $\mathrm{La}_{0.8} \mathrm{Sr}_{0.2} \mathrm{Cr}_{0.5} \mathrm{Fe}_{0.5} \mathrm{O}_{3-\mathrm{d}}$ as anode material on cathode-support SOFCs for direct hydrocarbon utilization. Mater.Res. Innovations. 2014, vol. 18, suppl. 4, pp. 132-136.

17. Lai K.Y., Manthiram A. Self-Regenerating Co-Fe Nanoparticles on Perovskite Oxides as a Hydrocarbon Fuel Oxidation Catalyst in Solid Oxide Fuel Cells. Chem. Mater. 2018, vol. 30, iss. 8, pp. 2515-2525.

18. Wei T., Zhou X., Hu Q., Gao Q., Han D., Lv X., Wang S. A high power density solid oxide fuel cell based on nanostructured $\mathrm{La}_{0.8} \mathrm{Sr}_{0.2} \mathrm{Cr}_{0.5} \mathrm{Fe}_{0.5} \mathrm{O}_{3-\delta}$ anode. Electrochim.Acta. 2014, vol. 148, pp. 3338. 
19. Gong M., Bierschenk D., Haag J., Poeppelmeier K.R., Barnett S.A., Xu C., Zondlo J.W., Liu X. Degradation of $\mathrm{LaSr}_{2} \mathrm{Fe}_{2} \mathrm{CrO}_{9-\delta}$ solid oxide fuel cell anodes in phosphine-containing fuels. $J$. Power Sources. 2010, vol. 195, iss. 13, pp. 4013-4021.

20. ChesnokovK.Yu., Markov A.A., Patrakeev M.V., Leonidov I.A., Murzakaev A.M., Leonidova O.N., Shalaeva E.V., Kharton V.V., Kozhevnikov V.L. Structure and transport properties of $\mathrm{La}_{0.5} \mathrm{Sr}_{0.5-\mathrm{x}} \mathrm{Ca}_{\mathrm{x}} \mathrm{FeO}_{3}$ §. Solid State Ionics. 2014, vol. 262, pp. 672-677.

21. Kolotygin V.A., Tsipis E.V., Patrakeev M.V., Waerenborgh J.C., Kharton V.V. Time degradation of electronic and ionic transport in perovskite-like $\mathrm{La}_{0.5} \mathrm{Ca}_{0.5} \mathrm{FeO}_{3-\delta}$. Mater.Lett.2019, vol. 239, pp. 167-171.

22. Kolotygin V.A., Tsipis E.V. Patrakeev M.V., Ivanov A.I., Kharton V.V. Stability, mixed conductivity, and thermomechanical properties of perovskite materials for fuel cell electrodes based on $\mathrm{La}_{0.5} \mathrm{~A}_{0.5} \mathrm{Mn}_{0.5} \mathrm{Ti}_{0.5} \mathrm{O}_{3-\delta}$,

$\mathrm{La}_{0.5} \mathrm{Ba}_{0.5} \mathrm{Ti}_{0.5} \mathrm{Fe}_{0.5} \mathrm{O}_{3-\delta}$, and $\left(\mathrm{La}_{0.5} \mathrm{~A}_{0.5}\right)_{0.95} \mathrm{Cr}_{0.5} \mathrm{Fe}_{0.5} \mathrm{O}_{3-\delta}(\mathrm{A}=\mathrm{Ca}, \mathrm{Ba})$. Russ. J. Electrochem. 2016, vol. 52, iss. 7, pp. 628-641.

23. Shannon R.D. Revised Effective Ionic Radii and Systematic Studies of InteratomieDistancesin Halides and Chaleogenides. ActaCryst. 1976, vol. A32, pp. 751-767.

24. Kolotygin V.A., Tsipis E.V., Markov A.A., Patrakeev M.V., Waerenborgh J.C., Shaula A.L., Kharton V.V. Transport and Electrochemical Properties of $\mathrm{SrFe}(\mathrm{Al}, \mathrm{Mo}) \mathrm{O}_{3-\delta}$. Russ. J. Electrochem. 2018, vol. 54, iss. 6, pp. 514-526.

25. Kharton V.V., Yaremchenko A.A., Patrakeev M.V., Naumovich E.N., Marques F.M.B. Thermal and chemical induced expansion of $\mathrm{La}_{0.3} \mathrm{Sr}_{0.7}(\mathrm{Fe}, \mathrm{Ga}) \mathrm{O}_{3-\delta}$ ceramics. J. Eur. Ceram. Soc. 2003, vol. 23, iss. 9, pp. 1417-1426.

26. Yaremchenko A.A., Kharton V.V., Kolotygin V.A., Patrakeev M.V., TsipisE.V., Waerenborgh J.C. Mixed conductivity, thermochemical expansion and electrochemical activity of $\mathrm{Fe}$ substituted ( $\mathrm{La}, \mathrm{Sr})(\mathrm{Cr}, \mathrm{Mg}) \mathrm{O}_{3-\delta}$ for solid oxide fuel cell anodes. J. Power Sources. 2014, vol. 249, pp. 483-496.

27. Mori M., Yamamoto T., Itoh H., Watanabe T.Compatibility of alkaline earth metal ( $\mathrm{Mg}, \mathrm{Ca}, \mathrm{Sr}$ )-doped lanthanum chromites as separators in planar-type high-temperature solid oxide fuel cells. $J$. Mater. Sci. 1997, vol. 32, iss. 9, pp. 24232431.

28. Höfer H.E., Schmidberger R. Electronic Conductivity in the $\mathrm{La}(\mathrm{Cr}, \mathrm{Ni}) \mathrm{O}_{3}$ Perovskite System. J. Electrochem. Soc. 1994, vol. 141, iss. 3, pp. 782-786.

29. Kharton V.V., Yaremchenko A.A., Naumovich E.N. Research on the electrochemistry of oxygen ion conductors in the former Soviet Union. II. Perovskiterelated oxides. J. Solid State Electrochem.1999, vol. 3, iss. 6, pp. 303326.

30. Yarmolenko S., Gordon K., Hancock B., Kharton V., SankarJ.Characterization of $\left(\mathrm{La}_{0.9} \mathrm{Sr}_{0.1}\right)_{0.95} \mathrm{Cr}_{0.85} \mathrm{Mg}_{0.10} \mathrm{Ni}_{0.05} \mathrm{O}_{3-\delta}$

Ceramics for Perovskite Related Membrane Reactor. ASME 2007 International Mechanical Engineering Congress and Exposition. 2007, vol. 13, pp. 215-223.

31. Kharton V.V., Marques F.M.B., Atkinson A. Transport properties of solid oxide electrolyte ceramics: a brief review. Solid State Ionics. 2004, vol. 174, iss. 1-4, pp. 135-149.

32. Raffaelle B., Anderson H.U., Sparlin D.M., Parris P.E. Transport anomalies in the high-temperature hopping conductivity and thermopower of Srdoped $\mathrm{La}(\mathrm{Cr}, \mathrm{Mn}) \mathrm{O}_{3}$. Phys. Rev. B. 1991, vol. 43, pp. 7991-7999.

33. Koc R., Anderson H.U. Electrical and thermal transport properties of $(\mathrm{La}, \mathrm{Ca})(\mathrm{Cr}, \mathrm{Co}) \mathrm{O}_{3}$. J. Eur. Ceram. Soc. 1995, vol. 15, iss. 9, pp. 867-874.

34. Vashook V., Vasylechko L., Zosel J., Gruner W., Ullmann H., Guth U. Crystal structure and electrical conductivity of lanthanum-calcium chromites-titanates 
$\mathrm{La}_{1-\mathrm{x}} \mathrm{Ca}_{\mathrm{x}} \mathrm{Cr}_{1-\mathrm{y}} \mathrm{Ti}_{\mathrm{y}} \mathrm{O}_{3-\delta} \quad(\mathrm{x}=0-1, \quad \mathrm{y}=0-1) . \quad J$. Solid State Chem. 2004, vol. 177, iss. 10, pp. 3784-3794.

35. Koc R., Anderson H.U. Investigation of strontium-doped $\mathrm{La}(\mathrm{Cr}, \mathrm{Mn}) \mathrm{O}_{3}$ for solid oxide fuel cells. J. Mater. Sci. 1992, vol. 27, iss. 21, pp. 5837-5843.

36. Markov A.A., Patrakeev M.V., Leonidov I.A., Kozhevnikov V.L. Reaction control and long-term stability of partial methane oxidation over an oxygen membrane. $J$. Solid State Electrochem. 2011, vol. 15, iss. 2, pp. 253-257.
37. Yaremchenko A.A., Kharton V.V., Valente A.A., Snijkers F.M.M., Cooymans J.F.C., Luyten J.J., Marques F.M.B. Performance of tubular $\mathrm{SrFe}(\mathrm{Al}) \mathrm{O}_{3-\delta}-\mathrm{SrAl}_{2} \mathrm{O}_{4}$ composite membranes in $\mathrm{CO}_{2^{-}}$and $\mathrm{CH}_{4}$ containing atmospheres. J. Membr. Sci. 2008, vol. 319, iss. 1-2, pp. 141-148.

38. Fischer II J.C., Chuang S.S.C. Investigating the $\mathrm{CH}_{4}$ reaction pathway on a novel LSCF anode catalyst in the SOFC. Catal.Commun. 2009, vol. 10, iss. 6, pp. 772-776.

\title{
BORK OKSID YANACAQ ELEMENTLORI ÜÇÜN ELEKTROD MATERIALLARI KIMI $\left(\mathrm{La}_{0.75} \mathrm{Ca}_{0.25}\right)_{0.95} \mathrm{Cr}_{1-X} \mathrm{Fe}_{X} \mathrm{O}_{3-4}$ PEROVSKITLORIN ISTIFADO PERSPEKTIVI
}

\author{
V.A. Kolotıin, A.I. Ivanov, N.B. Kostretsova, V.V. Xarton \\ REA-nin Bark Cisimlar Fizikasi Institutu \\ 142432 Rusiya, Çernoqolovka, akad.Osipyan küç., 2 \\ e-mail: kolotygin@issp.ac.ru
}

Taqdim olunan iş bərk oksid yanacaq elementlorinin katod va anodları üçün istifadə oluna bilan $\left(\mathrm{La}_{0.75} \mathrm{Ca}_{0.25}\right)_{0.95} \mathrm{Cr}_{1-x} \mathrm{Fe}_{x} \mathrm{O}_{3-\delta}$ perovskitlarin sintezina hasr olunub. Bu materiallar ortorombik struktura malikdilor, lakin 800-1000 K temperaturda quzdirdiqda romboedrik formaya keçirlar. Keçid temperaturu dəmirin miqdarından asılıdır. Xətti genişlənmə amsalı $(10.5-11.1) \times 10^{-6} \mathrm{~K}^{-1}$ intervalda dayişir, hacmi dayişiklar $0.16 \%$ təşkil edir.

Açar sözlor: perovskit, termiki genişlənma, faza keçidlari, xətti genişlənmə amsall, bark oksid elementlari.

\section{ПЕРОВСКИТОПОДОБНЫЕ ( $\left.\mathrm{La}_{0.75} \mathrm{Ca}_{0.25}\right)_{0.95} \mathrm{Cr}_{1-X} \mathrm{Fe}_{X} \mathrm{O}_{3-4}$ ДЛЯ ПОТЕНЦИАЛЬНОГО ИСПОЛЬЗОВАНИЯ В КАЧЕСТВЕ ЭЛЕКТРОДНЫХ МАТЕРИАЛОВ СИММЕТРИЧНЫХ ТВЕРДООКСИДНЫХ ТОПЛИВНЫХ ЭЛЕМЕНТОВ}

\section{В.А. Колотыгин, А.И. Иванов, Н.Б. Кострецова, В.В. Хартон}

\author{
Институт физики твердого тела РАН \\ 142432 Россия, Черноголовка, Московская область, ул.акад.Оссипьяна, 2, \\ e-mail: kolotygin@issp.ac.ru
}

\begin{abstract}
Работа посвящена синтезу и аттестации перовскитов $\left(\mathrm{La}_{0.75} \mathrm{Ca}_{0.25}\right)_{0.95} \mathrm{Cr}_{1-x} \mathrm{Fe}_{x} \mathrm{O}_{3-\delta}$ в качестве потенциальных катодов и анодов твердооксидных топливных элементов (ТОТЭ). Для материалов характерна орторомбическая структура на воздухе, в то время как при нагреве свыше 800-1100 К происходит обратимый переход структуры в ромбоэдрическую симметрию. Температура перехода растет с содержанием железа. Значения линейного коэффиичента термического расширения изменяются в интервале $(10.5-11.1) \times 10^{-6} K^{-1}$, слегка увеличиваясь при легировании материалов железом, в то время как объемные изменения при восстановлении не превышают $0.16 \%$. Электронная проводимость проявляет термически-активированный характер $u$ увеличивается при введении железа, предположительно благодаря росту числа узлов
\end{abstract}


доступных для электронного переноса. Данное поведение наблюдается в окислительных и восстановительных условиях. Низкий уровень электронной проводимости предположительно обуславливает недостаточно высокую каталитическую активность катодовна основе $\left(\mathrm{La}_{0.75} \mathrm{Ca}_{0.25}\right)_{0.95} \mathrm{Cr}_{1-x} \mathrm{Fe}_{x} \mathrm{O}_{3-\delta,}$ в то время как в анодных условиях электрохимическое поведение связано с рядом других факторов, таких как электродная микроструктура или поверхностные явления.

Ключевые слова: перовскит, фазовый переход, термическое расширение, химическое расширение, полная электропроводность, поляризаџионное сопротивление. 